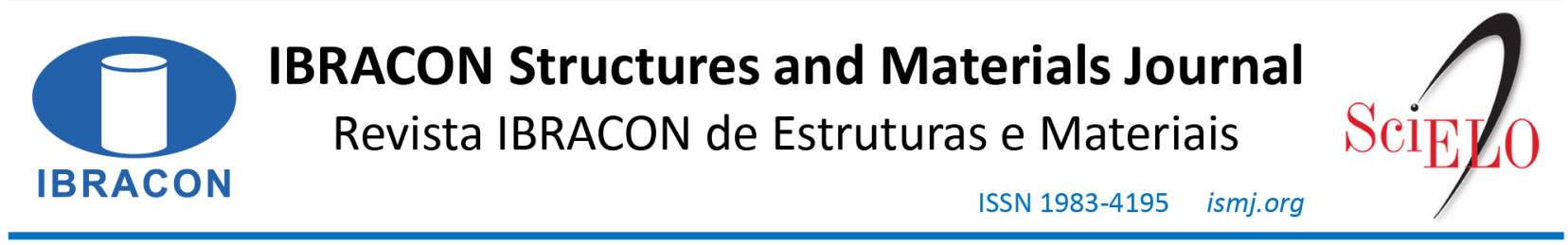

ORIGINAL ARTICLE

\title{
Effect of nano-silica on Portland cement matrices containing supplementary cementitious materials
}

\section{Efeito da nanossílica em matrizes de cimento Portland contento materiais cimentícios suplementares}

\author{
Thiago Melanda Mendes ${ }^{\mathrm{a}}$ if \\ Wellington Longuini Repette ${ }^{\mathrm{b}}$ (D)
}

${ }^{a}$ Universidade Tecnológica Federal do Paraná - UTFPR, Departamento de Engenharia Ambiental, Londrina, PR, Brasil

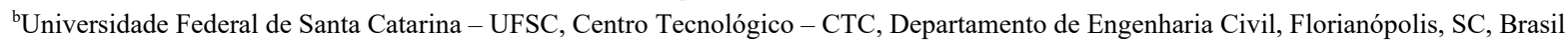

Received 09 June 2020

Accepted 31 December 2020

\begin{abstract}
For a controlled granulometry, this study evaluates the effect of nano-silica on mechanical and rheological properties, as well in the microstructure of Portland cement matrices containing a fixed amount of supplementary cementitious materials and three different types of cements. The rheological behavior of cement pastes was evaluated by rotational rheometry and mechanical performance was measured througth the compressive strength. The microstructure was analyzed by intrusion mercury porosimetry and scanning electron microscopy. There was an increasing on the viscosity of the cementitious matrices, as a consequence of the reduction in the inter particle separation of these suspensions. The optimum content of nano-silica varied according to $\mathrm{Ca} / \mathrm{Si}$ ratio of Portland cement matrices containing supplementary cementitious materials. The use of nano-silica allowed to modify the pore size distribution of cementitious matrices. And the structure of nano-silica in cementitious matrices has occurred in layers or agglomerates of nano-particles covered by hydration products.
\end{abstract}

Keywords: rheology, compressive strength, microstructure, porosity.

\begin{abstract}
Resumo: Para uma granulometria controlada, este estudo avalia o efeito da nanossílica nas propriedades mecânicas e reológicas, bem como na microestrutura de matrizes de cimento Portland contendo uma quantidade fixa de materiais cimentícios suplementares e três diferentes tipos de cimentos. O comportamento reológico das pastas cimentícias foi avaliado por reometria rotacional e o desempenho mecânico foi medido através da resistência à compressão. A microestrutura foi analisada por porosimetria de intrusão de mercúrio e microscopia eletrônica de varredura. Houve um aumento da viscosidade das matrizes cimentícias, como consequência da redução na distância de separação das partículas dessas suspensões. O teor ótimo de nanosílica variou de acordo com a relação $\mathrm{Ca} / \mathrm{Si}$ das matrizes de cimento Portland contendo materiais cimentícios suplementares. O uso da nanossílica permitiu modificar a distribuição do tamanho dos poros das matrizes cimentícias. E a estrutura da nanossílica nas matrizes cimentícias ocorreu em camadas ou aglomerados de nanopartículas recobertas por produtos de hidratação.
\end{abstract}

Palavras-chave: reologia, resistência à compressão, microestrutura, porosimetria de intrusão de mercúrio.

How to cite: T. M. Mendes and W. L. Repette, "Effect of nano-silica on Portland cement matrices containing supplementary cementitious materials," Rev. IBRACON Estrut. Mater., vol. 14, no. 4, e14401, 2021, https://doi.org/10.1590/S1983-41952021000400001

\section{INTRODUCTION}

The use of supplementary cementitious materials (SCM) is a currently trend, which can contribute to reducing the environmental impact of the Portland cement industry [1]. Much research has been carried out to obtain new alternative additions, such as basalt [2], marble [3], and granite fillers [4], or red ceramic waste [5]. Mendes et al. [6] showed a gain in compressive strength for mixtures containing $2.5 w t . \%$ of basaltic fillers, but for quantities greater than $5 w t . \%$, 
the mechanical properties become smaller than to the reference mixture. The use of nano-materials is another way, which can contribute to improve the mechanical performance of cement-based materials. The efficiency of nano-silica in the mechanical properties of cement-based materials, can be calculated by the ratio between the relative mechanical gain and the nano-silica content. Mendes et al. [7] showed that better efficiency was achieved for mixtures containing low amount of nano-silica.

Thus, the mixture of these alternative additions with nano-silica, nano-cement and carbon nanotubes, can avoid this loss in the mechanical performance of the cement-based materials. Comparing mixtures with 5 and $10 w t . \%$ of fly ash, or silica fume or nano-silica, Biricik and Sarier [8] revealed that formulations with nanosilica have the highest compressive strength, followed by the mixtures containing silica fume and fly ash. For mixtures formulated with 5 and $10 w t . \%$ of silica-fume and nano-silica, Tóbon et al. [9] demonstrated that the mixture formulated with nano-silica has a better mechanical performance than mixture formulated with silica fume. For concretes containing $1 \mathrm{wt} . \%$ of nano-silica or $10 \mathrm{wt} . \%$ of silica-fume and $1 \mathrm{wt} . \%$ of nano-silica, Jacob et al. [10] showed that the combined effect of silica fume and nano-silica leads to better mechanical performance. Zanon et al. [11] also showed better mechanical performance for mixtures formulated with $0.5 w t . \%$ of nano-silica and $10 w t . \%$ of silica-fume, when compared to the mixture containing only $0.5 w t . \%$ of nano-silica.

When nano-silica is the only supplementary cementitious material (SCM) used, for large quantities of this reactive amorphous silica, the improvement in the mechanical performance is mainly related to the pozzolanic reaction [7]. When combined with other supplementary cementitious material (SCM), the packing effect becomes important for small amounts of nano-silica, reaching a solubility limit of less than $1 w t . \%$ [12]. For mixtures containing supplementary cementitious material (SCM), there are no references about the combined effect of nano-silica and cement type on the rheological and mechanical properties, as well on the microstructure of Portland cement matrices. Thus, for a controlled granulometry, the present study aims to evaluate the effect of nano-silica on mechanical and rheological properties, as well on the microstructure of Portland cement matrices containing a fixed amount of supplementary cementitious materials and three different types of cement.

\section{MATERIALS AND EXPERIMENTAL PROGRAM}

A pure clinker $(\mathrm{CP})$ powder was obtained by ball milling of clinker received from Votorantim Cimentos, for 90 minutes and sieved in a 200 mesh $(75 \mu \mathrm{m})$. The setting time of pure clinker was controlled by the retarding effect of superplasticizer due to the complexation of $\mathrm{Ca}^{2+}$ ions by the superplasticizer [12]. Portland cements CPV-ARI Votorantim (CPV-V) and CPV-ARI InterCement (CPV-I) were also used as binders. These two Portland cements CPVARI were selected because they have different chemical compositions, mainly in the $\mathrm{Ca} / \mathrm{Si}$ ratios 2.22 and 3.01 for CPV-V and CPV-I, respectively. In a previous study [6], it was found that the fine (FF) and the coarse fractions (CF) of basaltic filler, showed similar performance when $15 w t . \%$ was added to a Portland CPV-ARI. Silica fume ELKEM 920U (SF), and nano-silicas Akzo Nobel Cembinder $8\left(\mathrm{nS}_{1}\right)$, Cembinder $30\left(\mathrm{nS}_{2}\right)$ and Cembinder $50\left(\mathrm{nS}_{3}\right)$ were used as supplementary cementitious materials (SCM).

The chemical composition of raw materials was measured in molten samples, using the P'ANalytical Axios Advanced fluorescence spectrometer. The specific Surface Area (S.S.A.) was measured by gas adsorption (B.E.T.) with BELSORP MAX equipment. For these measurements the samples were dried at $105^{\circ} \mathrm{C}$, and kept under vacuum of $68.9 \mathrm{~Pa}$ at $60^{\circ} \mathrm{C}$ for 24 hours. The density was determinate by picnometry of liquids (Table 1 ). The densities of nanosilicas $\mathrm{nS}_{1}, \mathrm{nS}_{2}$ and $\mathrm{nS}_{3}$ were calculated from density and mass concentration of suspensions: $1.4 \mathrm{~g} / \mathrm{cm}^{3}$ and $50 \%$, $1.10 \mathrm{~g} / \mathrm{cm}^{3}$ and $30 \%, 1.05 \mathrm{~g} / \mathrm{cm}^{3}$ and $15 \%$, respectively. BASF's ADVA 505 poly-carboxylic acid (PC) was used as a dispersant additive.

The mineralogical composition of pure clinker and Portland cements was obtained by X-ray diffraction of

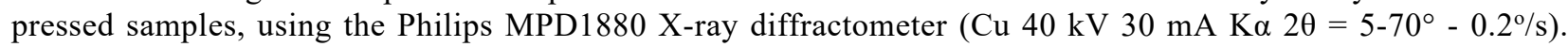
Transmission Electron Microscopy (TEM) of nano-silica suspensions was performed with Fei Tecnai G2 equipment, operating at 80 and $120 \mathrm{kV}$. The nano-silica samples were diluted to $1 \mathrm{mg} / \mathrm{ml}$ and sonicated for 30 minutes. Five milliliters $(5 \mu \mathrm{l})$ of these diluted suspensions, were dropped into a copper-carbon grid (300 mesh), and covered with Formvar. 
Table 1. Physical properties and chemical composition (wt.\%) of raw-materials

\begin{tabular}{|c|c|c|c|c|c|c|}
\hline Description & $\mathrm{SiO}_{2}$ & $\mathrm{Al}_{2} \mathrm{O} 3$ & $\mathrm{Fe}_{2} \mathrm{O}_{3}$ & $\mathrm{CaO}$ & $S S A\left(m^{2} / g\right)$ & Density $\left(\mathrm{g} / \mathrm{cm}^{3}\right)$ \\
\hline Pure Clinker (CP) & 20.0 & 4.92 & 3.34 & 59.9 & 0.91 & 3.15 \\
\hline P. Cement Votorantim (CPV-V) & 23.6 & 6.60 & 3.09 & 52.6 & 1.25 & 3.05 \\
\hline P. Cement InterCement (CPV-I) & 19.5 & 5.12 & 2.50 & 58.8 & 1.10 & 3.10 \\
\hline Basaltic Coarse Fraction (CF) & 51.8 & 16.3 & 11.3 & 8.80 & 1.14 & 2.85 \\
\hline Basaltic Fine Fraction (FF) & 51.0 & 15.1 & 13.0 & 9.26 & 3.20 & 2.85 \\
\hline Silica Fume (SF) & 95.0 & n.d. & n.d. & n.d. & 14.4 & 2.20 \\
\hline Cembinder $8\left(\mathrm{nS}_{1}\right)$ & n.d. & n.d. & n.d. & n.d. & 47.3 & 2.33 \\
\hline Cembinder $30\left(\mathrm{nS}_{2}\right)$ & n.d. & n.d. & n.d. & n.d. & 88.9 & 2.25 \\
\hline Cembinder $50\left(\mathrm{nS}_{3}\right)$ & n.d. & n.d. & n.d. & n.d. & 44.6 & 2.54 \\
\hline
\end{tabular}

The granulometric distribution of pure clinker, Portland cements, basaltic fillers and silica-fume was determined with Malvern 2200 laser granulometer. The granulometric distribution of nano-silicas was measured by Dynamic Laser Scattering (DLS), using Microtac Nano-Flex equipment. Part of Portland cements or pure clinker was replaced by silica fume and basaltic filler, an equal amount of these supplementary cementitious materials was used. Thus, these compositions of pure clinker or Portland cement, silica fume and basaltic fillers were combined with nano-silicas. The granulometric distribution of cementitious matrices was adjusted by Equation 1 [13], [14] with $\mathrm{D}_{\mathrm{L}}=100 \mu \mathrm{m}$; $\mathrm{D}_{\mathrm{S}}=0.001 \mu \mathrm{m}(1 \mathrm{~nm}) ;$ and distribution coefficients $q=0.37,0.50,0.55$ and 0.61 .

$$
C P F T=\left[\left(D_{P}^{q}-D_{S}^{q}\right) /\left(D_{L}^{q}-D_{S}^{q}\right)\right]
$$

where: CPFT $=$ cent percent finer than $(\%) ; D_{P}=$ Particle diameter $(\mu \mathrm{m}) ; D_{S}=$ smallest particle diameter $(\mu \mathrm{m})$; $D_{L}=$ Largest Particle diameter $(\mu \mathrm{m}) ; q=$ coefficient of distribution.

In previous studies [13], [14]; for cementitious matrices containing nano-silica, without supplementary cementitious materials (SCM), the water demand and the consumption of dispersant was adjusted to obtain a self-compacting rheological behavior for these suspensions. In this study, considering that the amount of SCM reaches $33 \%$ of the composition, the content of the dispersant was fixed at $2 w t . \%$.

The volumetric concentration of solids $\left(\mathrm{V}_{\mathrm{S}}\right)$ of the suspensions was calculated from water/solids ratio $(\mathrm{w} / \mathrm{s})$ and densities; the volumetric surface area (VSA) was calculated from product of the specific surface area (SSA) and the density of the compositions, following Funk and Dinger [15]. The initial porosity $\left(\mathrm{P}_{0}\right)$ was estimated using the linear packing model developed by $\mathrm{Yu}$ and Standish [16]. The inter particle separation (IPS) of mixtures was calculated from these results, following Funk and Dinger [15]. The nano-silica suspensions and the dispersant were previously diluted with deionized water. The mixing was performed in a laboratory mixer using a $6 \mathrm{~cm}$ diameter axial flow rod, cawles model. Applying the following process: (i) the dry powder was mixed at $586 \mathrm{rpm}$ for $60 \mathrm{~s}$; (ii) $2 / 3$ of the suspension (water + dispersant + nano-silicas) were added and mixed at $586 \mathrm{rpm}$ for $120 \mathrm{~s}$; (iii) $1 / 3$ of the suspension (water + dispersant + nano-silica) was mixed at $586 \mathrm{rpm}$ for $120 \mathrm{~s}$.

A temperature-controlled rheometer with concentric cylinders geometry was used to measure rheological properties of cement pastes. The rheograms were obtained with the control of the shear rate, varying from 10 to $100 \mathrm{~s}^{-1}$, in intervals of $10 \mathrm{~s}^{-1}$. The shear rate was increased from 10 to $100 \mathrm{~s}^{-1}$ (upper curve) and reduced from 100 to $10 \mathrm{~s}^{-1}$ (downs curve). The rheological behavior of cement pastes was measured 30 seconds after mixing. The tests were performed for $10 \mathrm{~g}$ of paste, maintained 30 seconds at each shear rate; the values were recorded in the last 3 seconds. All tests were performed at $23^{\circ} \mathrm{C}$. Bingham's model was applied to calculate the yield stress $\left(\tau_{0}\right)$ and the viscosity $(\eta)$ of the suspensions, considering the downs curve. Eight cylindrical specimens $(2: 5 \mathrm{~cm})$ were molded and compacted manually to avoid molding defects.

The Brazilian Standard ABNT NBR 8045 [17] establishes the accelerated compressive strength for concretes applying the boiling water method. According to this reference, after an initial curing period of 24 hours, the specimens shall be immersed in boiling water $\left(>100^{\circ} \mathrm{C}\right)$ for 2 hours. The specimens were kept at room temperature $\left(22^{\circ} \mathrm{C}\right)$ for 24 hours, and for 18 hours immersed in water at $85^{\circ} \mathrm{C}$. This curing method was employed in order to achieve this accelerated compressive strength of Portland cement matrices. For six specimens, the upper face of was sliced, resulting in a final height of $4 \mathrm{~cm}$. The compressive strength was measured by applying a loading rate of $2.5 \mathrm{MPa} / \mathrm{s}$. Two 
specimens was lathed, until they reached a diameter of $1 \mathrm{~cm}$ and a height of $2 \mathrm{~cm}$, these internal parts of the sample was broken and a small piece was used to perform the mercury intrusion porosimetry (MIP) and the scanning electron microscopy (SEM). The pore size distribution of mixtures was measured using a Micrometrics Pore Size equipment (contact angle $=140^{\circ}$ ). Microstructure of samples was analyzed by scanning electron microscope (SEM) coupled to an energy dispersive spectrometer (EDS) using Quanta 600 FEI-Philips equipment, operating at $25 \mathrm{kV}$. The gold coating was applied to the sample surface for this analysis.

\section{RESULTS AND DISCUSSIONS}

Figure 1 shows the diffractograms of pure clinker and Portland cements CPV-V and CPV-I. The characteristic peak of gypsum $\left(2 \theta=11.6^{\circ}\right)$ was identified only for the Portland cement CPV-V. A similar intensity for the tetra calcium ferro-aluminate phase $\left(\mathrm{C}_{4} \mathrm{AF}\right)$ was identified for all samples $\left(2 \theta=12.2^{\circ}\right.$ and $\left.60.1^{\circ}\right)$. Tricalcium aluminate $\left(\mathrm{C}_{3} \mathrm{~A}\right)$ was identified for the three binders $\left(2 \theta=33.2^{\circ}\right)$. Portland cement CPV-I has the largest amount of di and tricalcium silicates $\left(\mathrm{C}_{3} \mathrm{~S} / \mathrm{C}_{2} \mathrm{~S}\right)$, followed by Portland cement CPV-V and pure clinker $\left(2 \theta=29.5^{\circ}\right.$ and $\left.32.2^{\circ}\right)$.
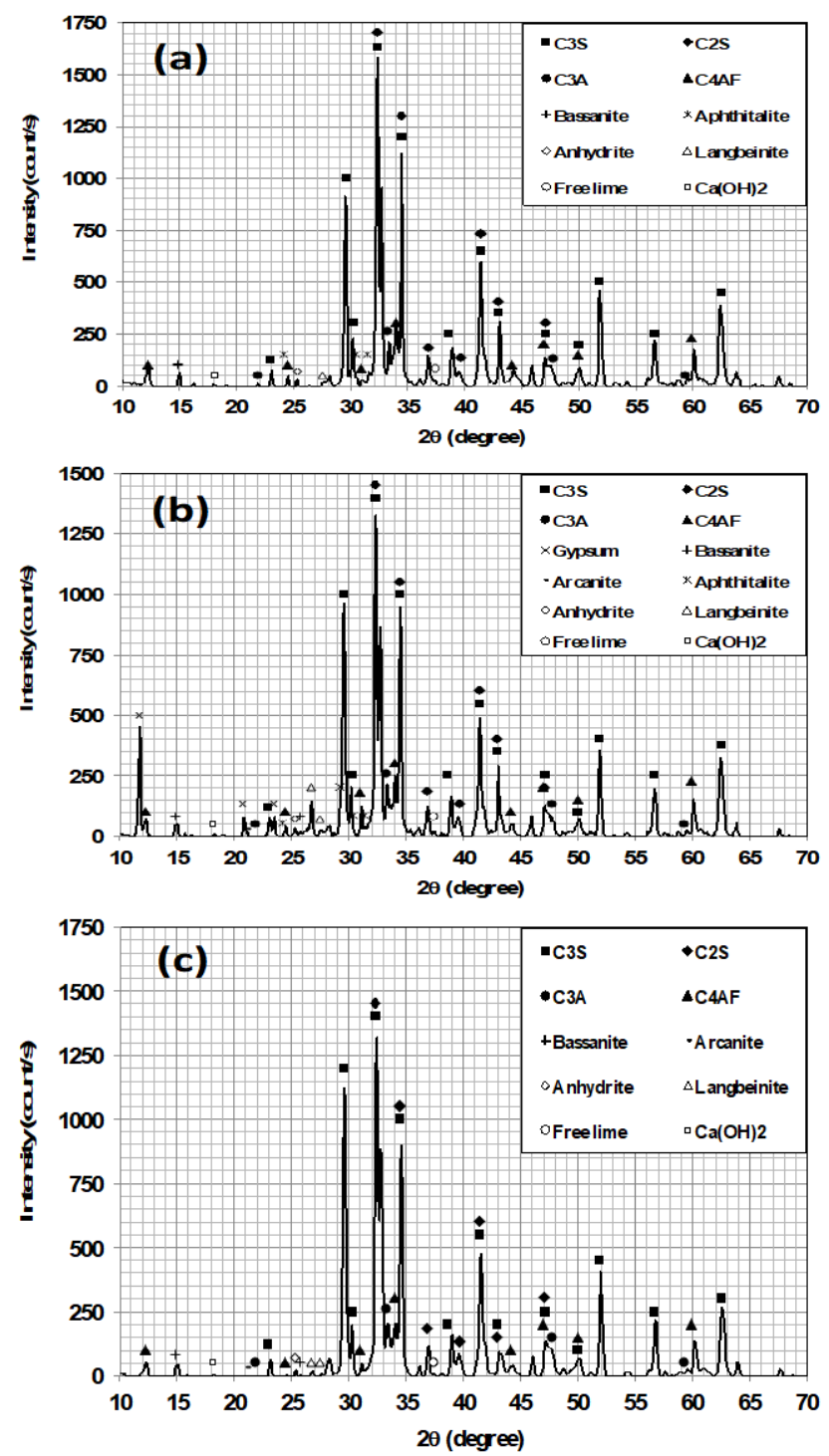

Figure 1. Diffractograms (a) Pure Clinker (b) Portland cement CPV-V (c) Portland cement CPV-I. $\left(\mathrm{C}_{3} \mathrm{~S}\right)-3 \mathrm{CaOSiO}_{2},\left(\mathrm{C}_{2} \mathrm{~S}\right)$ $2 \mathrm{CaOSiO}_{2},\left(\mathrm{C}_{3} \mathrm{~A}\right)-3 \mathrm{CaOAl}_{2} \mathrm{O}_{3},\left(\mathrm{C}_{4} \mathrm{AF}\right) 4 \mathrm{CaOAl}_{2} \mathrm{O}_{3} \mathrm{Fe}_{2} \mathrm{O}_{3}$, Gypsum - $\mathrm{CaSO}_{4} 2 \mathrm{H}_{2} \mathrm{O}$, Bassanite - $\mathrm{CaSO}_{4} 1 / 2 \mathrm{H}_{2} \mathrm{O}, \mathrm{Arcanite}^{-} \mathrm{K}_{2} \mathrm{SO}_{4}$, Anhydrite - $\mathrm{CaSO}_{4}$, Langbeinite - $\mathrm{K}_{2} \mathrm{Mg}_{2}\left(\mathrm{SO}_{4}\right)_{3}$, Aphthitalite - $(\mathrm{K}, \mathrm{Na})_{3} \mathrm{Na}\left(\mathrm{SO}_{4}\right)_{2}$, Free lime - $\mathrm{CaO}-\mathrm{Portlandite}-\mathrm{Ca}(\mathrm{OH})_{2}$. ASTM C1365 [18] 
Figure 2 shows the TEM micrographies of the nano-silicas Cembinder $8\left(\mathrm{nS}_{1}\right)$, Cembinder $30\left(\mathrm{nS}_{2}\right)$ and Cembinder $50\left(\mathrm{nS}_{3}\right)$. The nano-silica Cembinder 8 showed particles ranging from 10 to $60 \mathrm{~nm}$, Figure 2a. While, for the nano-silica Cembinder 30 the particle size ranges from 15 to $24 \mathrm{~nm}$, but some agglomerates larger than $76 \mathrm{~nm}$ can be found, Figure $2 \mathrm{~b}$. Figure $2 \mathrm{c}$ shows the TEM micrography of the nano-silica Cembinder 50, with a large agglomerate of particles, and some particles with a diameter ranging from 7 to $14 \mathrm{~nm}$. Figure $3 \mathrm{a}$ shows the particle size distribution of nano-silicas. The particle size distribution of nano-silica Cembinder $8\left(\mathrm{nS}_{1}\right)$ presents a considerable number of particles coarser than $100 \mathrm{~nm}(0.1 \mu \mathrm{m})$, and a smaller number of nanoparticles $(<100 \mathrm{~nm})$, demonstrating the agglomerated condition observed by the TEM image of Figure 2a. The nano-silica Cembinder $30\left(\mathrm{nS}_{2}\right)$ presented three populations of particles, composed by a small quantity of particles coarser than $100 \mathrm{~nm}(0.1 \mu \mathrm{m})$, probably agglomerates of small particles; a population of particles between 10 and $100 \mathrm{~nm}(0.01-0.1 \mu \mathrm{m})$, which are clear observable in the TEM image of Figure $2 \mathrm{~b}$; and a considerable population of particles smaller than $5 \mathrm{~nm}(0.005 \mu \mathrm{m})$. Finally, the nano-silica Cembinder $50\left(\mathrm{nS}_{3}\right)$ present a continuous granulometry of particles ranging from 10 and $1000 \mathrm{~nm}(0.01-1 \mu \mathrm{m})$, and a secondary population of particle between 2 and $10 \mathrm{~nm}(0.002-0.01 \mu \mathrm{m})$. Figure $2 \mathrm{c}$ reveals the presence of particles in this interval, as well agglomerates of nano-particles greater than 100 nanometers $(0.1 \mu \mathrm{m})$. Thus, considering the specific surface area (Table 1) and the particle size distribution of nano-silicas, the presence of this number of particles smaller than $5 \mathrm{~nm}$ $(0.005 \mu \mathrm{m})$ resulted in the highest specific surface area $\left(88.9 \mathrm{~m}^{2} / \mathrm{g}\right)$ for the nano-silica Cembinder $30\left(\mathrm{nS}_{2}\right)$. While, the similar values of specific surface area of nano-silicas Cembinder $8(\mathrm{nS} 1)$ and Cembinder $50\left(\mathrm{nS}_{3}\right), 47.3$ and $44.6 \mathrm{~m}^{2} / \mathrm{g}$, respectively, suggest the agglomerated condition for these both raw-materials.

Figure $3 \mathrm{~b}$ present the granulometry of pure clinker, and Portland cements CPV-V and CPV-I, they showed a very similar particle size distribution, clearly finer than pure clinker. Figure $3 \mathrm{c}$ shows the granulometric distribution of the supplementary cementitious materials. Considering the specific surface area and the particle size distribution, the highest value observed for silica fume, despite of the granulometry observed, suggests its agglomerated condition.

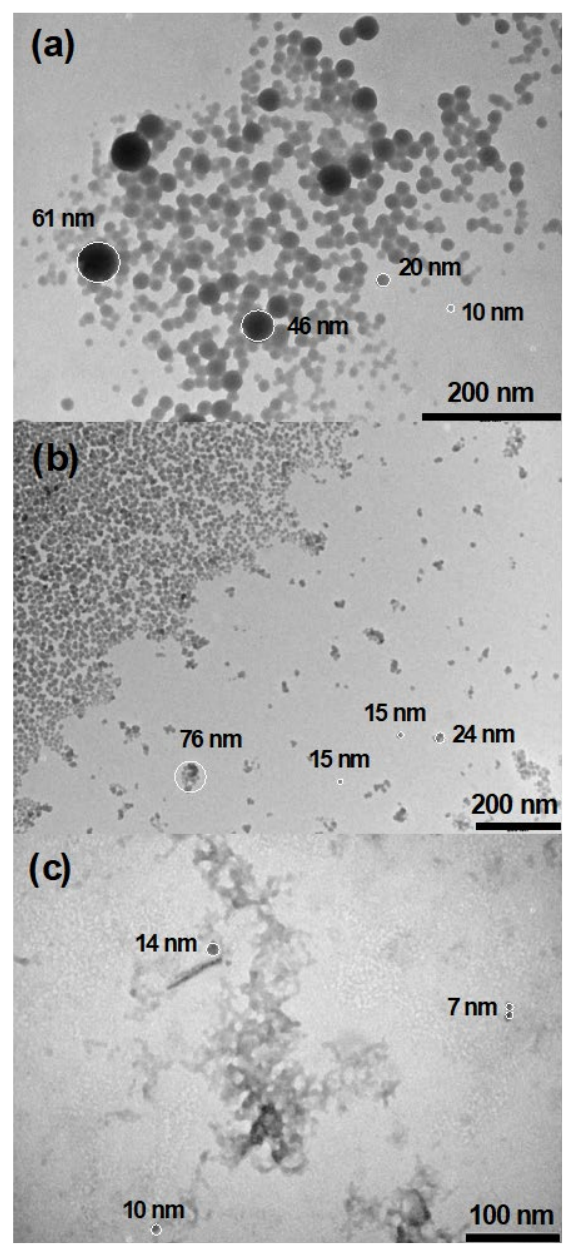

Figure 2. Transmission electron micrographies of nano-silicas (a) Cembinder 8 (b) Cembinder 30 and (c) Cembinder 50 

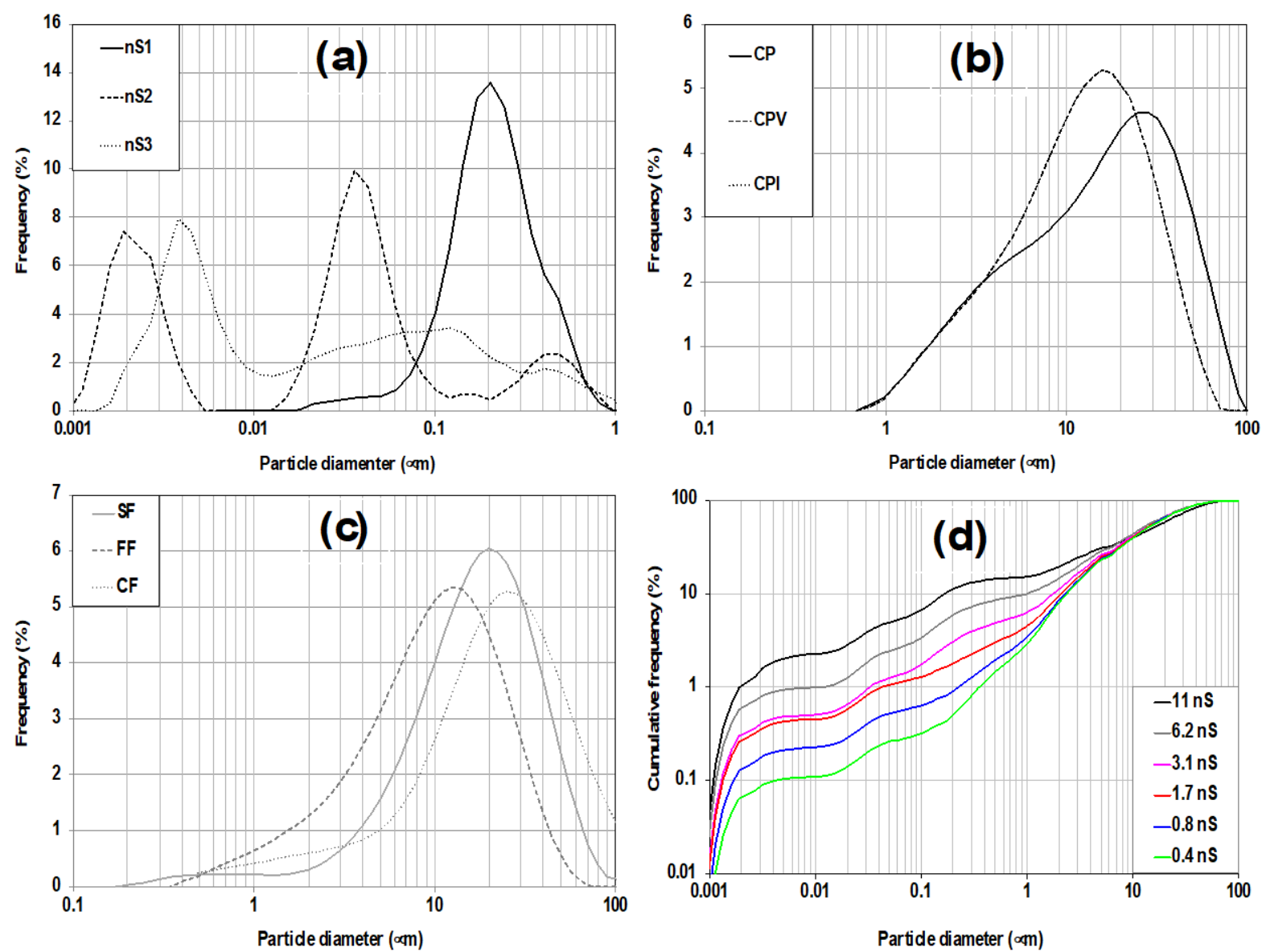

Figure 3. Particle size distribution (a) Nano-silicas (b) Cements and Clinker (c) Supplementary Cementitious materials (d) Mixtures

Table 2 shows the compositions of these formulations, which contain 11, 6.2, 3.16 and $1.70 \mathrm{wt} . \%$ of nano-silicas, respectively. For mixtures containing 0.85 and $0.42 w t . \%$ of nano-silicas, rates were obtained by dividing each amount nano-silica from the previous formulation by 2 .

Table 2. Composition of mixtures (wt.\%)

\begin{tabular}{cccccccc}
\hline Mixture & $\mathbf{1 1} \mathbf{~ n S}$ & $\mathbf{6 . 2} \mathbf{~ S}$ & $\mathbf{3 . 1} \mathbf{~ n S}$ & $\mathbf{1 . 7} \mathbf{n S}$ & $\mathbf{0 . 8 5} \mathbf{n S}$ & $\mathbf{0 . 4 2} \mathbf{~ S S}$ \\
\hline Cement or Clinker & 59.34 & 62.54 & 64.56 & 65.53 & 66.10 & 66.38 \\
\hline Basaltic Filler & 14.84 & 15.64 & 16.14 & 16.38 & 16.53 & 16.60 \\
\hline Silica Fume & 14.84 & 15.64 & 16.14 & 16.38 & 16.53 & 16.60 \\
\hline Cembinder $8\left(\mathrm{nS}_{1}\right)$ & 6.26 & 4.49 & 1.95 & 0.64 & 0.32 & 0.16 \\
\hline Cembinder 30 $\left(\mathrm{nS}_{2}\right)$ & 2.73 & 1.32 & 0.94 & 0.80 & 0.40 & 0.20 \\
\hline Cembinder 50 $\left(\mathrm{nS}_{3}\right)$ & 1.99 & 0.38 & 0.26 & 0.27 & 0.13 & 0.06 \\
\hline
\end{tabular}

Table 3 lists the results of water/solids (w/s), the volumetric concentration of solids $\left(\mathrm{V}_{\mathrm{S}}\right)$, the volumetric surface area (VSA), the estimated porosity $\left(\mathrm{P}_{0}\right)$, the calculated inter-particle separation (IPS) and the rheological properties: apparent yield stress $\left(\tau_{0}\right)$ and viscosity $(\eta)$. The results of some mixtures and their rheological properties were not presented, because they could not be measured or molded. As the content of nano-silica increases the water demand also increase, as a consequence of the high volumetric surface area (VSA) of the mixtures. The values of inter-particle separation (IPS) are lower than those of mixtures without supplementary cementitious materials (SCM), for mixtures containing only nano-silicas and Portland cements or pure clinker [13], [14]. This difference is mainly related to the 
greater specific surface area of silica-fume and basaltic fillers. Thus, the type of cement did not affect the rheological behavior of cementitious matrices. In most of the studied mixtures, the dispersant content used was able to keep the yield stress below $1 \mathrm{~Pa}$. However, for mixtures containing $11 \mathrm{wt} . \%$ of nano-silica, the yield stress reached values around $4 \mathrm{~Pa}$. The same trend was observed for mixtures containing $11 \mathrm{wt} \%$ of nano-silica, without SCM [13], [14]. But as the particles become closer the energy needed to keep them moving also increases. Figure 4 shows the effect of interparticle separation (IPS) on the viscosity of cement pastes formulated with Portland cements, pure clinker, nano-silica and SCM.

Table 3. Composition and physical characteristics of suspensions

\begin{tabular}{|c|c|c|c|c|c|c|c|c|}
\hline Mixture & $P C$ & $w / s(\%)$ & $V s(\%)$ & $V S A\left(m^{2} / \mathrm{cm}^{3}\right)$ & $P_{0}(\%)$ & $\operatorname{IPS}(n m)$ & $\tau_{0}(\mathrm{~Pa})$ & $\eta$ (Pa.s) \\
\hline$C P+11 n S$ & 2.0 & 53.68 & 39.24 & 26.55 & 39.44 & 34.05 & n.d. & n.d. \\
\hline$C P+1.7 n S$ & 2.0 & 25.73 & 56.81 & 12.65 & 33.23 & 20.76 & n.d. & n.d. \\
\hline$C P+0.85 n S$ & 2.0 & 22.35 & 60.17 & 11.08 & 32.66 & 15.98 & n.d. & n.d. \\
\hline$C P+0.42 n S$ & 2.0 & 20.56 & 62.12 & 10.30 & 32.38 & 12.71 & 4.33 & 0.07 \\
\hline$C P V-V+11 n S$ & 2.0 & 52.66 & 40.12 & 27.32 & 39.60 & 30.63 & n.d. & n.d. \\
\hline$C P V-V+6.2 n S$ & 2.0 & 30.07 & 53.72 & 20.08 & 36.40 & 14.39 & n.d. & n.d. \\
\hline$C P V-V+3.1 n S$ & 2.0 & 25.80 & 57.32 & 15.96 & 34.42 & 13.78 & n.d. & n.d. \\
\hline$C P V-V+1.7 n S$ & 2.0 & 24.86 & 58.13 & 13.86 & 33.40 & 15.78 & 0.57 & 0.03 \\
\hline$C P V-V+0.85 n S$ & 2.0 & 22.57 & 60.42 & 12.49 & 32.92 & 13.17 & 0.01 & 0.02 \\
\hline$C P V-V+0.42 n S$ & 2.0 & 20.48 & 62.69 & 11.74 & 32.64 & 9.42 & 0.01 & 0.14 \\
\hline$C P V-I+11 n S$ & 2.0 & 52.55 & 39.96 & 26.87 & 38.86 & 32.27 & 4.08 & 0.01 \\
\hline$C P V-I+6.2 n S$ & 2.0 & 30.30 & 53.36 & 19.66 & 35.54 & 16.41 & 0.98 & 0.06 \\
\hline$C P V-I+3.1 n S$ & 2.0 & 26.04 & 56.67 & 15.47 & 33.46 & 16.92 & 0.54 & 0.03 \\
\hline$C P V-I+1.7 n S$ & 2.0 & 23.12 & 59.54 & 13.50 & 32.48 & 14.70 & 0.01 & 0.10 \\
\hline$C P V-I+0.85 n S$ & 2.0 & 20.38 & 59.48 & 11.93 & 31.90 & 17.82 & 0.40 & 0.06 \\
\hline$C P V-I+0.42 n S$ & 2.0 & 19.64 & 62.67 & 11.15 & 31.61 & 11.73 & 0.01 & 0.16 \\
\hline
\end{tabular}

* Mixtures CPV-V was formulated with the fine fraction of basaltic filler

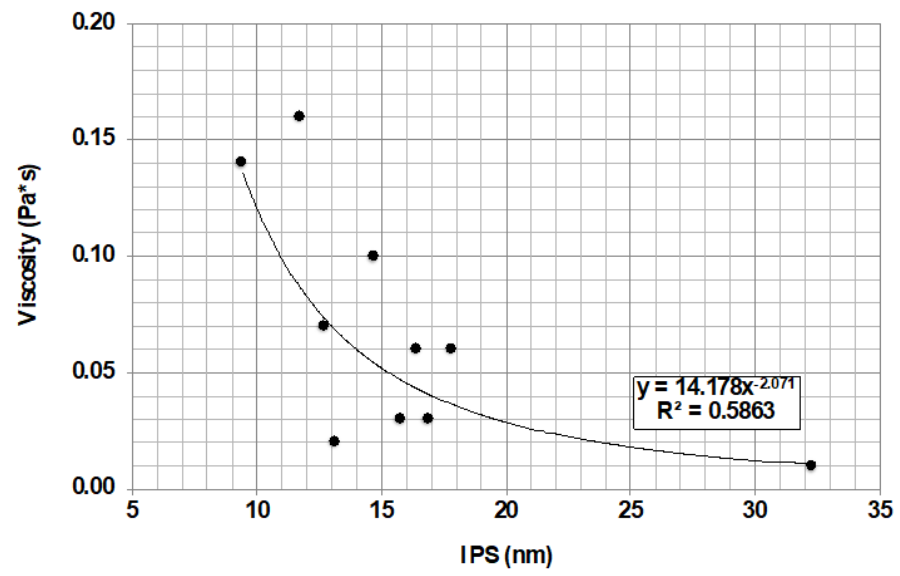

Figure 4. Effect of IPS on viscosity of cement pastes

The Figure 5a shows the effect of water/solids ratio on the compressive strength of cementitious matrices containing nano-silica and SCM. When large amounts of nano-silica were added, an increase in the water demand was necessary, as seen in Table 3, leading to a reduction in compressive strength. The continuous line represents the adjusted exponential equation for all mixtures. The dashed and dotted lines represent 1.25 and 0.75 of the continuous line. Figure $5 \mathrm{~b}$ shows that the mixtures formulated with pure clinker and nano-silicas, follow the same exponential trend expected for cementitious materials. However, an atypical value (red dot), demonstrated the occurrence of the optimum 
content of nano-silica, that is, the maximum packing for the composition containing $0.85 \mathrm{wt} . \%$ of nano-silica. The same situation was observed in Figure $5 \mathrm{c}$, where the mixture containing $0.85 \mathrm{wt} . \%$ of nano-silica represents the optimum content or maximum packing for the Portland cement CPV-I. Figure $5 \mathrm{~d}$ shows that the mixture containing $0.42 w t . \%$ of nano-silica represents the optimum content for the Portland cement CPV-V. This difference between the limit of solubility of nano-silica in the Portland cement matrices containing supplementary cementitious materials, can be explained by the $\mathrm{Ca} / \mathrm{Si}-\mathrm{Al}-\mathrm{Fe}$ ratios of these formulations. For the compositions containing pure clinker and Portland cement CPV-I the $\mathrm{Ca} / \mathrm{Si}$-Al-Fe ratios vary from 0.68 to 0.85 . In matrices formulated with the Portland cement $\mathrm{CPV}-\mathrm{V}$ this value ranges from 0.57 to 0.70 . These values were calculated considering the chemical composition of Pure clinker and Portland cements, as well the silica fume and the coarse and fine fractions of basaltic fillers. Since these supplementary cementitious materials shall exhibit considerable reactivity due to their nucleation and pozzolanic effects, even for the siliceous fillers by the use of heated curing.
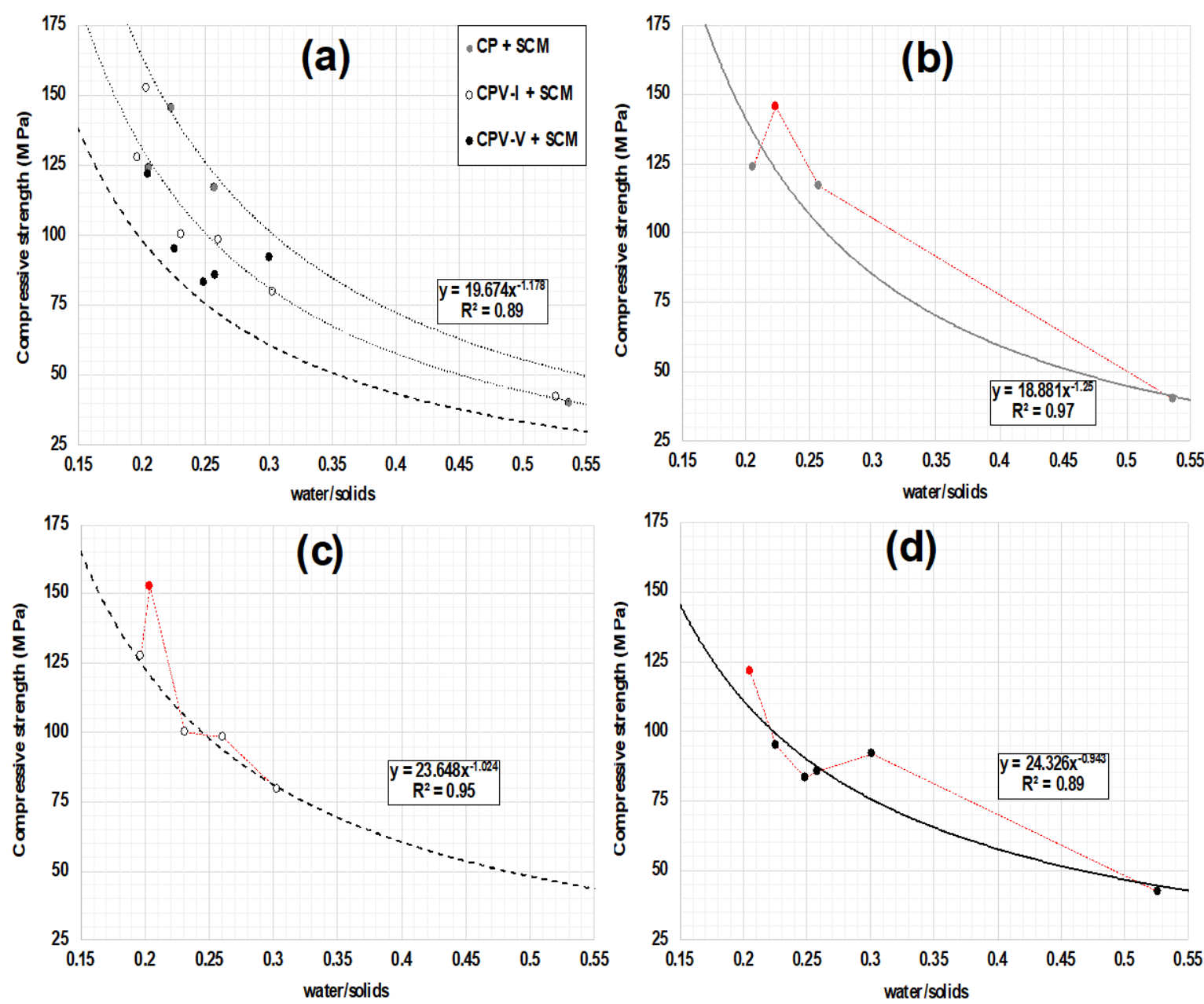

Figure 5. Effect of water/solids on the compressive strength (a) all mixtures (b) Pure clinker (c) Portland cement CPV-I (d) Portland cement CPV-V

Figure 6 shows the pore size distribution and the effect of porosity $\left(\mathrm{P}_{0}\right)$ on the mechanical performance of cementitious matrices containing nano-silica, with and without SCM. Porosity is closely related with water/solids ratio of these mixtures, capillary pores $(0.01-1 \mu \mathrm{m})$ and the pores of air-entrapped bubbles $(10-1000 \mu \mathrm{m})$ were observed in these three formulations studied. For the nanometric pores $(<100 \mathrm{~nm}$ or $0.1 \mu \mathrm{m})$, part of this porosity resulted from the capillary pores, and varied due to the different water/solids in the mixtures. Comparing the mixtures containing CPV-V or $\mathrm{CP}+\mathrm{SCM}+11 \mathrm{nS}$, Figure $6 \mathrm{a}$ and $6 \mathrm{~b}$, a change in the pores smaller than $10 \mathrm{~nm}$ or a bimodal pore size distribution, was observed for the mixture formulated with pure clinker. This same difference in the pore size distribution was 
observed for mixtures containing pure clinker and nano-silica, with and without SCM, Figure $6 \mathrm{~b}$ and $6 \mathrm{c}$. As these mixtures studied used the same amount of nano-silica, the CPV-V cement and pure clinker did not show a considerable difference in chemical or mineralogical composition. The different specific surface areas of these binders led to a change in the pore size distribution. Mendes and Repette [13], [14] showed that this change in nanometric porosity varies according to the nano-silica content and the inter-particle separation. The arrangement of nano-silica in the microstructure of the cementitious matrix, has changed from a layered adsorbed structure, to a porous structure, or to an agglomerated structure of nanoparticles. If nano-silica adsorbs on the surface of coarser grains, this change in microstructure varies according to the specific surface area of the adsorbent material. Despite these differences observed in the nanometric porosity, Figure $6 \mathrm{~d}$ shows that the mechanical properties of cement matrices containing nano-silica with or without SCM, are closely related to the total porosity.
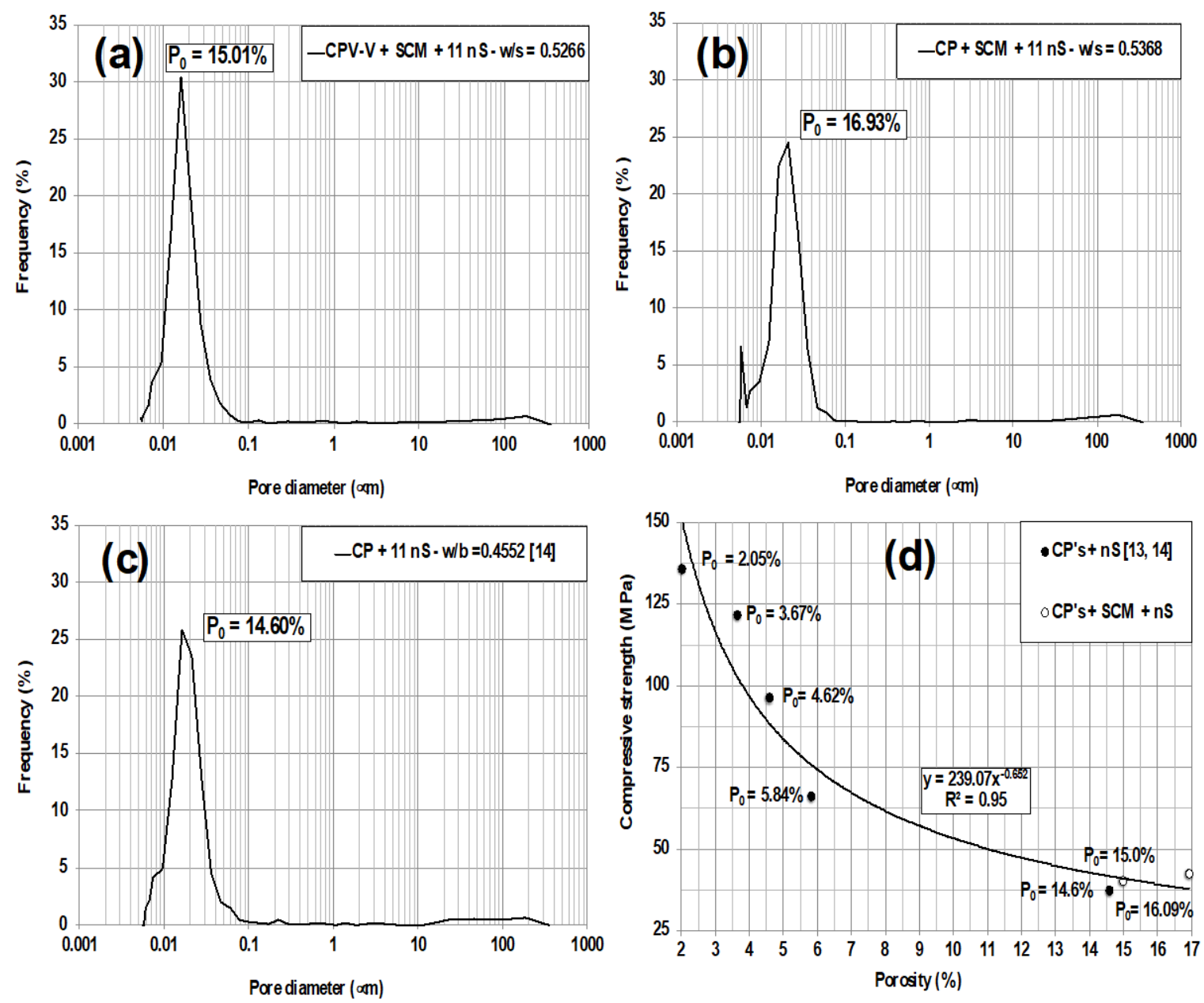

Figure 6. Mercury intrusion porosimetry (a) $\mathrm{CPV}-\mathrm{V}+\mathrm{SCM}+11 \mathrm{nS}$ (b) $\mathrm{CP}+\mathrm{SCM}+11 \mathrm{nS}$ (c) $\mathrm{CP}+11 \mathrm{nS}$ and [14] (d) Compressive strength vs Porosity of Portland cement matrices containing nano-silica with and without SCM [13], [14]

Figure 7 shows the scanning electron micrographs of the mixtures CPV-I $+\mathrm{SCM}+0.85 \mathrm{nS}$ and $\mathrm{CP}+\mathrm{SCM}+0.85 \mathrm{nS}$, which achieved the highest compressive strengths, 152.5 and $145.5 \mathrm{MPa}$, respectively. Figures $7 \mathrm{a}$ and $7 \mathrm{~b}$ show the microstructure of nano-silica in the cementitious matrices. As seen, nanoparticles are arranged in a layered structure and some agglomerates of nano-silica, have also been observed. Figure $7 \mathrm{c}$ and $7 \mathrm{~d}$ also shows these agglomerates of nano-silica. Figure 8a presents the chemical composition obtained by the electron dispersive scattering probe (EDS) of the region delimited in Figure 7c. The presence of calcium and silicon ions indicates that these agglomerates can be composed of: nano-silica coated with hydration products such as C-S-H and calcium hydroxide; hydration products like $\mathrm{C}-\mathrm{S}-\mathrm{H} / \mathrm{C}-\mathrm{A}-\mathrm{H}$, or even both together. Figures $7 \mathrm{e}$ and $7 \mathrm{f}$ show some agglomerates of nanoparticles, and the structure 
arranged in layers. Figure $8 \mathrm{~b}$ shows the chemical composition of the region of Figure 7e, obtained by the EDS probe. A similar content of calcium and silicon, indicates the same condition for the agglomerates of nano-particles seen in Figure $7 \mathrm{~d}$. This layered nanoparticles structure can probably be composed by nano-silica coated by hydration products, or the hydration products containing nanoinclusions of nano-silica.

\section{CONCLUSIONS}

The high specific surface area of nano-silica and supplementary cementitious materials increases the water demand and, consequently, the viscosity of cement pastes.

The optimum content of nano-silica varies according to $\mathrm{Ca} / \mathrm{Si}$ ratio of Portland cement matrices containing supplementary cementitious materials.

Nano-silica showed a layered or agglomerated structure, modifying the pore size distribution of cementitious matrices containing supplementary cementitious materials.

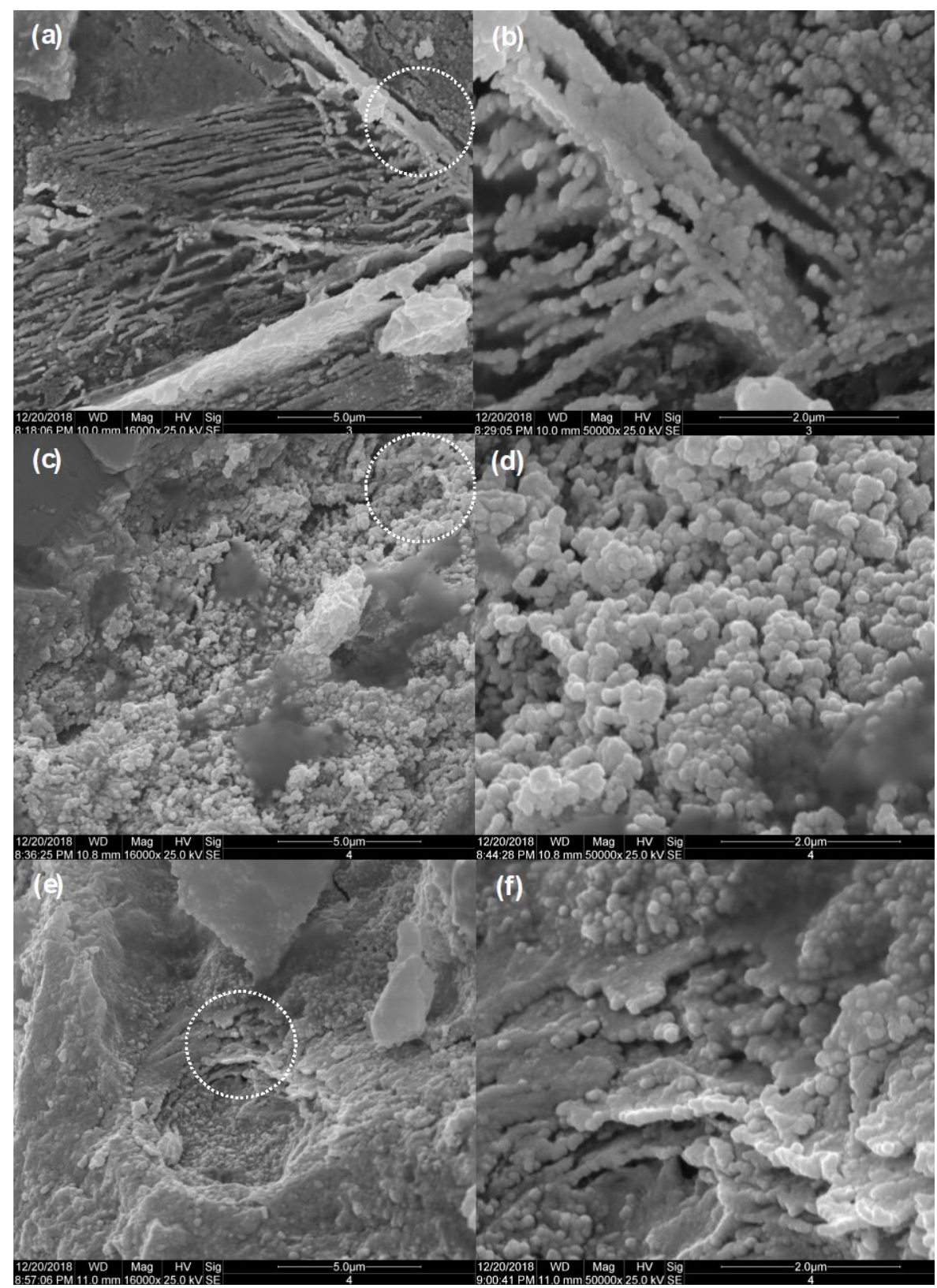

Figure 7. SEM micrographies (a, b) CPV-I + SCM + 0.85 nS (c-d) Mixture CP + SCM + 0.85 nS 


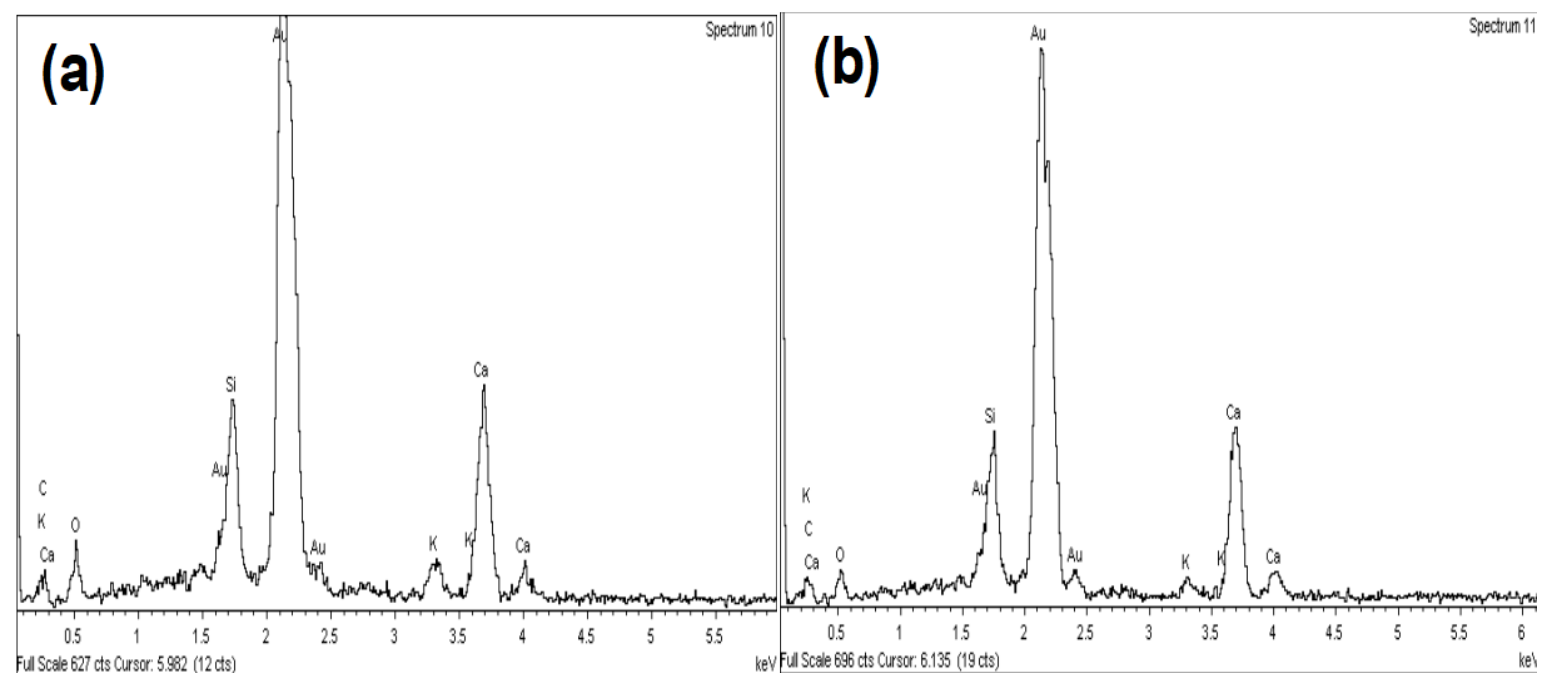

Figure 8. Chemical composition obtained by EDS (a) Figure 7d and (b) Figure 7e

\section{ACKNOWLEDGEMENTS}

The authors acknowledge the Araucaria Foundation, Coordination for the Improvement of Higher Education Personnel (CAPES) and National Council of Scientific and Technological Development (CNPq).

\section{REFERENCES}

[1] European Cement Association, Activity Report 2018. Brussels: CEMBUREAU, 2018. Accessed: June 9, 2019. [Online]. Available: https://cembureau.eu/media/1818/actvity-report-2018.pdf

[2] L. Laibao, Z. Yunsheng, Z. Wenhua, L. Zhiyong, and Z. Lihua, "Investigation the influence of basalt as mineral admixture on hydration and microstructure formation mechanism of cement," Constr. Build. Mater., vol. 48, pp. 434-440, 2013, http://dx.doi.org/10.1016/j.conbuildmat.2013.07.021.

[3] H. Y. Aruntas, M. Guru, M. Dayi, and I. Tekin, "Utilization of waste marble dust as an additive in cement production," Mater. Des., vol. 31, no. 8, pp. 4039-4042, 2010, http://dx.doi.org/10.1016/j.matdes.2010.03.036.

[4] M. Vijayalakshimi, A. S. S. Sekar, and G. Ganeshm, "Strength and durability properties of concrete made with granite industry waste," Constr. Build. Mater., vol. 46, pp. 1-7, 2013, http://dx.doi.org/10.1016/j.conbuildmat.2013.04.018.

[5] A. L. Castro, R. F. C. Santos, K. M. Gonçalves, and V. A. Quarcioni, "Characterization of blended cements with red ceramic industry waste," Ceramica, vol. 63, pp. 65-76, 2017, http://dx.doi.org/10.1590/0366-69132017633652036.

[6] T. M. Mendes, L. Guerra, and G. Morales, "Basalt waste added to Portland cement," Acta Sci. Technol., vol. 38, no. 4, pp. 431-436, 2016, http://dx.doi.org/10.4025/actascitechnol.v38i4.27290.

[7] T. M. Mendes, D. Hotza, and W. L. Repette, "Nanoparticles in cement based materials: a review," J. Adv. Mater. Rev., vol. 40, no. 1, pp. 89-96, 2015.

[8] H. Biricik and N. Sarier, "Comparative study of the characteristics of nano-silica-, silica-fume - fly ash-incorporated cement mortars," Mater. Res., vol. 17, no. 3, pp. 570-582, 2014, http://dx.doi.org/10.1590/S1516-14392014005000054.

[9] J. I. Tóbon, O. J. Restrepo, and J. Payá, "Comparative analysis of performance of portland cement blended with nanosilica and silica fume," Dyna, vol. 77, no. 163, pp. 37-46, 2010. Accessed: June 9, 2019. [Online]. Available: http://www.scielo.org.co/scielo.php?pid=S0012-73532010000300004\&script=sci_arttext\&tlng=en

[10] J. S. Jacob, A. G. Mascelani, R. L. R. Steinmetz, F. A. Dalla Costa, and O. A. Dalla Costa, "Use of silica fume and nano-silica in mortars attacked by acids present in pig mature," Procedia Struct. Integr., vol. 11, pp. 44-51, 2018, http://dx.doi.org/10.1016/j.prostr.2018.11.007.

[11] T. Zanon, R. Schmalz, and F. G. S. Ferreira, "Evaluation of nano-silica effects on concrete submitted to chloride ions attack," Rev. ALCONPAT, vol. 8, no. 2, pp. 138-149, 2018, http://dx.doi.org/10.21041/ra.v8i2.274.

[12] T. M. Mendes, W. L. Repette, and P. J. Reis, "Effects of nano-silica in mechanical properties and microstructure of ultra-highperformance concrete," Ceramica, vol. 63, no. 365, pp. 387-394, 2017, http://dx.doi.org/10.1590/0366-69132017633672037.

[13] T. M. Mendes and W. L. Repette, "Effect of nano-silica on Portland cement matrix," Rev. IBRACON Estrut. Mater., vol. 12, no. 6, pp. 1383-1389, 2019, http://dx.doi.org/10.1590/s1983-41952019000600009. 
[14] T. M. Mendes and W. L. Repette, "Nano-silica added to Portland cement," Acta Sci. Technol., 2021. (in press).

[15] J. E. Funk and D. Dinger, Predictive Process Control of Crowed Particulate Suspension, 1st ed. London: Kluwer Publishers, 1994.

[16] A. B. Yu and N. Standish, "Estimation of the porosity of particle mixtures by a linear-mixture packing model," Ind. Eng. Chem. Res., vol. 30, no. 6, pp. 1372-1385, 1991, http://dx.doi.org/10.1021/ie00054a045.

[17] Associação Brasileira de Normas Técnicas, Concreto - Determinação da Resistência Acelerada à Compressão - Método da Água em Ebulição, ABNT NBR 8045, 1993.

[18] American Society for Testing Materials, Standard Method for Determination of the Proportion on Phases of Portland Cement and Portland Cement Clinker Using Powder Diffraction Analysis, ASTM C1365, 2011.

Author contributions: TMM: conceptualization, data curation, formal analysis, methodology, writing; WLR: funding acquisition, supervision.

Editors: Fernando S. Fonseca, Guilherme Aris Parsekian. 